EXPERIENTIAL FUNCTION USED BY TUMOING, THE MAIN CHARACTER IN SI TUMOING MANGGORGA ARI SOGOT NOVEL

\begin{abstract}
AN ARTICLE
Submitted in Partial fulfillment of the Requirements for the Degree of Sarjana Sastra
\end{abstract}

By:

OCTAVIANI HUTABALIAN

Registration Number: 2132220011

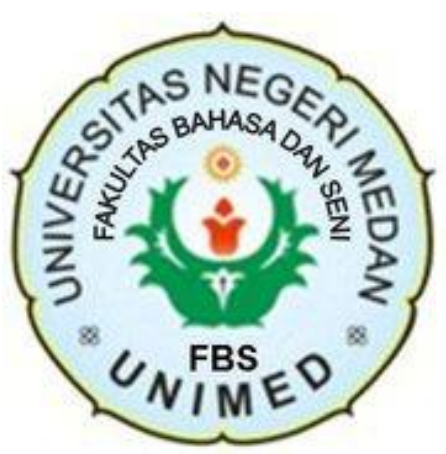

ENGLISH AND LITERATURE DEPARTMENT

FACULTY OF LANGUAGE AND ARTS

STATE UNIVERSITY OF MEDAN

2018 


\section{ARTIKEL}

\section{Experiential Function Used by Tumoing, The Main Character in $\mathrm{Si}$ Tumoing Manggorga Ari Sogot Novel}

Disusun dan Diajukan oleh:

Octaviani Hutabalian

NIM. 2132220011

\section{Telah diverifikasi dan dinyatakan memenuhi syarat untuk diunggah pada jurnal online}

Medan, Januari 2018

Menyetujui

Dosen Pembimbing Skripsi I

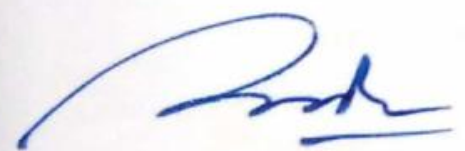

Morada Tetty, S.S., M.Hum.

NIP.19740524200701 2002
Dosen Pembimbing Skripsi II

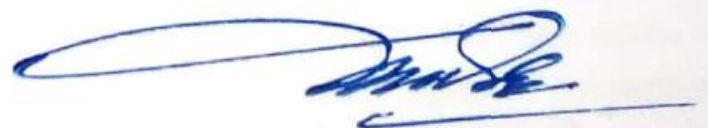

Prof. Dr. Zainuddin, DIP.TEFL., M.Hum.

NIP. 195201021980121001

Ketua Prodi Sastra Inggris

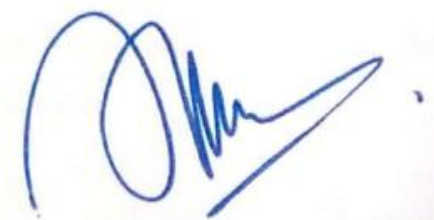

Juli Rachmadani Hasibuan, S.S, M.Hum.

NIP. 198207112008012008 


\title{
EXPERIENTIAL FUNCTION USED BY TUMOING, THE MAIN CHARACTER IN SI TUMOING MANGGORGA ARI SOGOT NOVEL
}

\author{
*Octaviani Hutabalian \\ ** Morada Tetty, S.S., M.Hum. \\ **Prof. Dr. Zainuddin, DIP.TEFL., M.Hum.
}

\begin{abstract}
Hutabalian, Octaviani, 2132220011. Experiential Function Used By Tumoing, The Main Character In Si Tumoing Manggorga Ari Sogot Novel. A Thesis, English and Literature Department, Faculty of Language and Arts, State University of Medan. 2018.
\end{abstract}

The study investigates the aplication of Halliday's theory of experiential function into Batak Toba clauses and to identify the types of experiential functions and the manners in which experiential functions are used by Tumoing in Saut Poltak Tambunan's novel "Si Tumoing Manggorga Ari Sogot". The study was conducted to describe type of process, participants function and circumstatial elements of experiential function in the novel. The study applied descriptive qualitative method. The data were taken from the utterances produced by the main character. The finding showed there were 6 types of processes, 14 types of participants and 8 circumtances in the dialogues of Tumoing. The dominant type of process was Relational process $(35,70 \%)$ while Actor as the dominant type of participant (13, $42 \%)$ and Location as the dominant type of circumtance $(48,70 \%)$. The findings also showed that the main character was honest person and friendly person. It's explained by the relational process i.e using atributing and identifying.

Keywords: Experiential Function, Batak Toba clauses, Si Tumoing Manggorga Ari Sogot, Relational Process

\footnotetext{
*Graduate Status

**Lecturer Status
} 


\section{INTRODUCTION}

\section{Background of The Study}

Language is inseparable in human's life since no way to replace its role and function to express what people think and feel. It conveys meaning from someone's intention, emotion as well as feeling as stated by Bloor and Bloor in Harahap (2012:1), language is a system of meanings. When people communicate by using language, their language acts are the expression of meaning. Language as a meaning has a very important function in people daily life. People need language to socialize with others because they don't want to get isolated. According to Halliday (2002:3) one of the functions of language is to provide for interaction between people, by allowing the expression of statuses, judgments and the like ; and this includes participation in linguistic interaction.

Halliday (1978:60) stated that language has three functions which are known as metafunction of language. Metafunction of language consits of ideational, interpersonal, and textual. Ideational states that all adult language are organized around the small number of functional components. Interpersonal is one of the three metafunctions (the others being ideational and textual). And textual is one of the three functional diversifications (metafunctions) which enables the speaker or writer to construct texts. Language is used to describe, which is known as ideational meaning is classified into two sub functions, the experiential meaning and the logical meaning. The ideational function of language which is concerned with the transmission of ideas is called transitivity. 
One of the functions of language is to describe experience. This is to say that language is used by human beings to represent their experience. Technically the function of language to represent experience is termed the experiential function, as one component of the metafunction as advocated by Halliday as in Saragih (2014). Reality in text or discourse is realized by the experience which is realized in the experiential function.

In the fact, the transitivity system is necessary part of literary text. It is used to understand realization or representation or symbolization of experiential function in situational context, Jamaluddin (2016:2). This study is used to understand the transitivity system is part of the experiential function has a necessary role to express ideational meaning in the novel. According to Emilia in Jamaluddin (2016:3) stated that the ideational metafunction is to do with how language is used to represent experience, or to organize, understand, and express our perceptions of the world and our consciousness. Specifically, the experiential function belongs to ideational metafunction, and the transitivity system construes the world of experience into manageable set of process types Halliday (1994a:106), which is also termed as the clause as representation. The three elements of the transitivity system -participants, process types, and circumstances - are, in nature, constructing the events, Bumela in Jamaluddin (2016:3)

Batak Toba language is one of the local languages in Indonesia..This language is spoken in North Sumatra and used as means communication among Batak Toba people's society. The origin of Batak Toba language comes from Samosir Island. This language also is used in some distric in North Sumatera 
such as Toba Samosir, Dairi, Tapanuli Tengah, Humbang Hasundutan,South Tapanuli, and surrounding areas. According to Sinaga (2002:15) Batak Toba language also has own grammar. The grammar of Batak Toba language is different from English. Eventhough there are some similarities between them but the way of constructing the sentence, Batak Toba language has different way.

In the previous study about experiential function, Rambe (2015) in the study about Experiential meaning in Batak Angkola wedding ceremony found that The parts of experiential meaning are shown in every step of Batak Angkola wedding ceremony, Material process are the dominant process show in every step of Batak Angkola wedding ceremony, and it is usually related to the daily activities of Batak Angkola society.

\section{METHODOLOGY}

This research used Descriptive qualitative research. This method used the grounded theory by Bogdan, \& Biklen (2009:10). descriptive qualitative method is the collection of data to give an explanation or description about the event or accuracy of the report.

\section{DATA AND DATA ANALYSIS}

It was explained in the previous chapter that the data of the study were selected and collected from 24 chapters of Si Tumoing Manggorga Ari Sogot novel. The main goal in this research are to find out the kinds of experiential function used by Tumoing, the main character in Si Tumoing Manggorga Ari 
Sogot novel, and the manner in which experiential functions are used in $S i$ Tumoing Manggorga Ari Sogot novel.

\section{Process}

a. Material Process

1. Tuat ho sian kareta mi (Chapter 2, Page 25, Paragraph 3)

'You have to get down from your motorcycle'

\section{b. Mental Process}

1. Huboto do i (Chapter 9, Page 89, Paragraph 8)

'I know about it'

c. Relational Process

1. Ho do dongan hu tu dolok tu toruan salelengon (Chapter 1, Page 17, Paragraph 1)

"You are my friend for up and down"

\section{d. Behavioural Process}

1. Huida ma jolo tusi (Chapter 4, Page 45, Paragraph 5)

"I will look there"

e. Verbal Process

1. Natorashu pe ndang hea disungkun ahu (Chapter 4, Page 49, Paragraph 8) "My parent also never ask me"

\section{f. Existential Process}

1. ndang laho adong be siguluton (Chapter 8, Page 82, Paragraph 8)

"There is nothing to be survived" 


\section{Participant}

1. Нu boan pe hamu mardalani tu luar negeri. (Chapter 1, Page 21, Paragraph 3)

"I will bring you to go to abroad" (Actor, Goal)

2. Teal ho so ditanda ho dirim (Chapter 2, Page 27, Paragraph 2)

“You don't know your self”' (Senser, Phenomenon)

3. Tung parjehe do ho (Chapter 2, Page 33, Paragraph 2)

"You are a traitor" (Token, Value)

4. Asa sombu do roham (Chapter 1, Page 16, Paragraph 2)

"So your heart are satisfied" (Carrier, Atribute)

5. Sude jolma do adong hurangna (Chapter 4, Page 45, Paragraph 5)

"Everybody have their weekness"(Possessor, Possessed)

6. Sihol ninna rohana mangallang boras mera (Chapter 7 , Page 74, Paragraph 9)

"His heart miss red rice" (Behaver)

7. Natorashu pe ndang hea disungkun ahu (Chapter 4, Page 49, Paragraph 8)

"My parent also never ask me" (Sayer, Verbiage)

8. Alai adong muse do lobina (Chapter 4, Page 45, Paragraph 5)

"But there are also their excess" (Existent)

\section{Circumtances}

1. Ho do dongan hu tu dolok tu toruan salelengon (Chapter 1, Page 17, Paragraph 1) 
"You are my friend for up and down" (Extent)

2. Sai dilambunghu do ho salelengon (Chapter 1, Page 17, Paragraph 2)

"You are always in my side" (Location)

3. Na baru ro sian huta dope ahu (Chapter 9, Page 94, Paragraph 3)

"I come from hometown recently" (Manner)

4. Marsak do si Marisa alani ho (Chapter 2, Page 33, Paragraph 3)

"Marissa is sad because of you" (Cause)

5. Ho do tongtong na mangantusi sude na hansit na sai solot dirohangki (Chapter 3, Page 38, Paragraph 10)

"You always understand me for all my pain in my heart" (Contigency)

6. Nunga mangan au raphon si Goldu nakkin (Chapter 7, Page 78, Paragraph 5) "I have eat my lunch with Goldu just now"(Accompaninment)

7. Pangido sipahopot mata (Chapter 2, Page 32, Paragraph 6)

“Ask the witness to influence her mind"(Role)

8. Ho do saksi manang angka aha padan nami (Chapter 1, Page 17, Paragraph 1) "You are my witness whatever our promise" (Matter)

\section{FINDINGS AND DISCUSSION}

\section{Findings}

Based on the data analysis, it was found that there were six types of process in the dialogues, consist of Material Process was 98 (24, $43 \%)$, Mental Process was $91(23,59 \%)$, Relational Process was 147 (35,70 \%), Behavioural 
Process was 23 (5,73\%), Verbal Process was 26 (6,50\%) and Existential Process was $16(4,00 \%)$. There were 14 types of participant found in the dialogue, Actor was $80(13,42 \%)$, Goal was $41(7,76 \%)$, Senser was $74(12,41 \%)$, Pheneomenon was $64(11,63 \%)$, Token was 48 (8,14\%), Value was $42(7,04 \%)$, Carrier was $79(13,25 \%)$, Attribute 78 (13,08\%), Possessor was 14 (2,34\%), Possessed $14(2,34 \%)$, Behaver was 12 (2,01\%), Sayer was 20 (3,35\%), Verbiage was $13(2,18 \%)$, and Existent was $16(3,58 \%)$. The w riter also found that there were 8 out of 9 types of circumtances in the dialogue. There were Extent was $7(5,54 \%)$, Location was 75 (48,70 \%), Manner was $12(8,79 \%)$, Cause was $1(0,64 \%)$, Contigency was $3(2,94 \%)$, Accompaninment was $7(5,54$ $\%)$, Role was $42(28,27 \%)$ and Matter was $7(4,54 \%)$.

It also was found that the dominant type of process was Relational process $(35,70 \%)$ while Actor as the dominant type of participant $(13,42 \%)$ and Location as the dominant type of circumtance $(48,70 \%)$. Relational Process is the dominant one because it is explaining about atributing and identifying. Tumoing's dialogues in the story used identifying and attributing something/somebody more. actor came out as the dominant participant. It was one of participants who did something or action. Actor came out as the dominant participant because the second dominant type of process was material process. It means that Tumoing as the main charater reflect a character of doer, not as a thinker. Location came out as the dominant on circumtance because Tumoing as the main character in the novel mostly used circumtances as the adverb that tells about the places or situation in which the characters were described in his dialogues. 


\section{Discussion}

After analyzing and answer all the research problems, there were some important points to be discussed. In this research, it was found that the most dominant process was Relational process while the dominant types of participant was actor and dominant type of circumtance was location. It means that the different object used in analysis have different uttarances and reveal different result too. It depends on the contents and character of the story. The effect of the dominant type of process that occured in this novel is to describe how is the condition of the main character of this novel named Tumoing, not only describing the appearance but also the chracteristics of Tumoing to build up the language style of writing in Batak Toba's literary works.

\section{CONCLUSION AND SUGGESTION}

\section{Conclusion}

The six types of process were found in Tumoing's dialogues. They are Material, Mental, Relational, Behavioural, Verbal and Exisential Process. The type of participants that used in Tumoing's dialogues were Actor, Goal, Senser, Phenomenon, Token, Value, Carrier, Attribute, Possessor, Possessed, Behaver, Sayer, Verbiage, and Existent. The types of circumtance that found in Tumoing's dialogues were Extent, Location, Manner, Cause, Contigency, Accompaninment, Role and Matter. It also was found that the dominant process was Relational Process $(35,70 \%)$, the dominant participant was Actor $(13,42 \%)$, and dominant type of circumtance was Location $(48,70 \%)$. 
Relational process contrues being and relation among entities through identification and atribution. This process stresses on defyning something. In this case Tumoing utttarances mostly contains sentences that define something when he speaks to other characters. The identifying process showed that Tumoing was a friendly person. It was often explained by the way he defined the identity of something or somebody. He regards everything is closed to him and has a good relationshp. While the attributing process showed that the character of Tumoing was also a honest person. It was proved in his dialogues. He mostly used atrributing process to describe the quality or classification of something or somebody. He also used it to express the fact. In his dialogues, the main character mostly express his experience by identifying and attributing the environment around him .

The actor came out as the dominant participant. It was one of participants who did something or action. Actor came out as the dominant participant because the second dominant type of process was material process. It means that Tumoing as the main charater reflect a character of doer, not as a thinker. It means that Tumoing as the main charater in the novel did the action dominantly.

Location came out as the dominant on circumtance because Tumoing as the main character in the novel mostly used circumtances as the adverb that tells about the places or situation in which the characters were described in his dialogues. It is caused by his experience that refers to environments where he did the activties. In his dialogues he mostly used the circumtance of location to support the using of places. He visited many places during as foreigner in 
Malaysia. He described his location related to time and place before he went to Malaysia and after he worked in Malaysia.

\section{Suggestion}

It is suggested for the reader to know more about how experiential function represented in the local lierary works is and what kind of experiential function used in the Toba Batak Novel, for the students of English Literature should learn more about the using of experiential function especially the representation of experiential function in Batak Toba literary works, for the further researcher who wants to conduct experiential function by analyzing literary works of other ethnics and for Batak Toba people, as a reference to learn about the novel written in Batak Toba language.

\section{REFERENCES}

Bloor, T, \& Bloor,M. 2004. The Functional Analysis Of English (2nd ed.) London:Arnold.

Bogdan, R. C \& Biklen, S. K. 2009. Qualitative Research for Education: An Introduction to Theory and Methods. (4th ed.). New York: Pearson Education group.

Eggins, Suzanne. 2004. An Introduction to Systemic Functional Linguistics. London: Printer Publisher Ltd.

Florentina.A.S. 2012. Types of Process in Pitbull Song. English Education and Literature Deparment, Faculty of Language and Arts, the State University of Medan.

Halliday, M.A.K. 1994. An Introduction to Functional Grammar, $\left(2^{\text {nd }}\right.$ ed). New York: Oxford University Press.

Halliday, M.A.K. 1994. Text and Discourse. New York: Oxford University Press.

Harahap, Henny Fauziah. 2012. Taransitivity in Barack Obama's Speeches. Thesis, English Education and Literature Deparment, Faculty of Language and Arts, the State University of Medan. 
Hermansyah.2014. Experiential Function in Verbal and Non - Verbal Modes of WWF Advertisements. English Applied Linguistics Study Program, Postgraduate School, State University of Medan.

Jamaluddin, Ikbal. 2016. The Analysis of Experiential Function in Public Speeches of Bill and Melinda Gates. 16 Februari 2017. http://repository.usu.ac.id.

Liping, Chen. 2014. Experiential Metafunctional Analysis of Winston S. Churchill's Speech on Hitler's Invasion of the U.S.S.R.International Journal of English Language Vol.7, No.9. School of Foreign Languages, Guangdong University of Petrochemical Technology, Guangdong, China.

Khairunnisah. 2015. The Experiential Function Used by Men and Women in Writing Opinion at www.kompasiana.com. English Applied Linguistics Study Program, Postgraduate School, State University of Medan.

Nasution, Novita Husna. 2017. Experiential Function in Facebook Statuses by Male and Female Users. English Applied Linguistics Study Program, Post Graduate School, State University of Medan..

Rambe, Sari Marina. 2015. The Experiential Meaning in Batak Angkola Wedding Ceremony. English Applied Linguistics Study Program, Postgraduated School, State University of Medan.

Saragih, A. 2014. Discourse Analysis: A Study On Discourse Based On Systematic Functional Linguistic Theory. Unimed, Medan.

Saragih, A. 2006. Introducing Systematic Functional Grammar. Medan : FBS UNIMED.

Sinaga, Bernika.C.U. 2016. Transitivity System Used by Saara Crewe, The Main Character In A Little Princess Novel.English Education and Literature Deparment, Faculty of Language and Arts, the State University of Medan.

Sinaga, Margareth Fransisca. 2010. The Analysis of Process in Selected Speeches of President Susilo Bambang Yudhoyono. English Education and Literature Deparment, Faculty of Language and Arts, the State University of Medan.

Sinaga, Anicetus B. 2002. Tata Bahasa Batak Toba. Medan: Percetakan Bina Media Perintis.

Sinar, Tengku Silvana. 2002. An Introduction to Systemic Functional Linguistics. London: Continuum International Publishing Group.

Sipayung, Kammer Tuahman. 2016. Metafunction Realization on Students' Descriptive Paragraphs. International Journal of English Language and Literature Studies Vol 8, No. 6 